\title{
Suatu Kasus Dispensable Set pada Fuzzy N-Soft Set
}

\author{
Athia Nurindah Sari, Admi Nazra*, Dan Haripamyu \\ Jurusan Matematika, \\ Fakultas Matematika dan Ilmu Pengetahuan Alam, Universitas Andalas, \\ Kampus UNAND Limau Manis Padang-25163, Indonesia.
}

\begin{abstract}
Abstrak
Konsep tentang fuzzy $N$-soft set (FNSS) merupakan gabungan dari konsep fuzzy set dengan $N$-soft set untuk menyelesaikan suatu permasalahan dalam proses pengambilan keputusan. Dalam penelitian ini dikaji suatu kasus dimana dimungkinkan terdapatnya sekumpulan parameter, yang disebut dengan dispensable set, dari sekian banyak parameter pada suatu FNSS, sedemikian sehingga sekumpulan parameter tersebut dapat diabaikan dalam suatu proses pengambilan keputusan, dalam artian, bilamana sekumpulan parameter tersebut dipertimbangkan ataupun tidak, hasil keputusan tidak berubah. Metode yang digunakan dalam menyelesaikan suatu permasalahan dalam proses pengambilan keputusan ini adalah metode skor. Suatu hasil yang menarik dari kajian ini adalah bahwa pada suatu FNSS, untuk sepasang parameter $(a, b)$ dari sekian parameter yang ada, dimungkinkan terdapatnya pola urutan dari peringkat dan nilai keanggotaan dari objek-objek, sedemikian sehingga, bilamana dihitung skor dari setiap objek tersebut, baik dengan mempertimbangkan parameter $a$ dan $b$ ataupun tidak, akan memberikan kesimpulan yang sama.

Kata kunci:Dispensable Set, Fuzzy N-Soft Set, Masalah Pengambilan Keputusan.
\end{abstract}

\begin{abstract}
A fuzzy N-soft set (FNSS) concept combines fuzzy set with $N$-soft set to solve a decision-making problem. In this study, we analyse a case of a decision-making problem where there exists a subset of parameters in the FNSS, called dispensable set, such that the subset can be ignored in the decision-making problem. This means that if the subset of parameters is considered or not, the decision will be the same. The method used in solving a problem in the decision-making process is the scoring method. An exciting result of this study is that, in a FNSS, for a pair of parameters $(a, b)$ of the existing parameters, it is possible to have a sequential pattern of ranking and membership values of objects, such that, when calculated the score of each object, whether by considering the parameters $a$ and $b$ or not, will give the same conclusion.

Keywords:Dispensable Set, Fuzzy N-Soft Set, Decision-Making Problem.
\end{abstract}

2000 Mathematics Subject Classification: 03E72, 03B52

Received: 30-8-2021, Revise: 7-12-2022, Accepted: 28-12-2021.

*Korespondensi Penulis: nazra@sci.unand.ac.id 


\section{Pendahuluan}

Sebagian besar masalah yang dihadapi umat manusia di dunia melibatkan data tegas atau pasti (crisp). Sebagai contoh, ada masalah yang dapat diselesaikan dengan menggunakan data yang bersifat tegas atau pasti seperti menimbang sekarung beras, mengukur tinggi pohon dan sebagainya. Namun, terdapat juga masalah yang melibatkan data yang tidak tegas atau tidak pasti. Sebagai contoh, misalkan terdapat sekarung beras seharga 180.000 rupiah. Menurut Ibu Ani harga beras tersebut sangat mahal tetapi menurut Ibu Ina harga beras tersebut wajar. Akibatnya terjadi perbedaan pendapat antara Ibu Ani dengan Ibu Ina. Inilah yang disebut data yang tidak pasti atau tidak tegas, karena data tersebut tergantung kepada siapa yang menilai (dalam hal ini disebut pengambil keputusan). Oleh karena itu, salah satu kajian untuk menyelesaikan masalah tersebut adalah dengan menerapkan konsep matematika berdasarkan ketidakpastian atau ketidakjelasan.

Pada tahun 1965, Zadeh [3] memperkenalkan teori fuzzy set (FS) untuk pertama kalinya. Teori $F S$ biasanya digunakan untuk mempermudah pengambilan keputusan terhadap beberapa objek pada permasalahan yang mengandung unsur ketidakpastian atau ketidakjelasan saat memberikan suatu penilaian pada objek-objek tersebut dari sudut pandang satu parameter atau atribut tertentu. Suatu ukuran terhadap ketidakpastian atau ketidakjelasan tersebut disebut dengan nilai keanggotaan dari objek yang dinilai, yang dinyatakan dengan suatu nilai tunggal dalam interval $[0,1]$.

Kemudian, karena masih ada keterbatasan pada teori $F S$ dimana objek-objek yang dinilai hanya terkait dengan satu parameter maka Molodtsov [1] memperkenalkan teori soft set (SS) pada tahun 1999. Dalam teori SS dikaji tentang pengelompokan objek-objek yang memenuhi atau tidak memenuhi suatu parameter tertentu dan paramter yang dipertimbangkan lebih dari satu. Terkait atau tidaknya suatu objek dengan suatu parameter dinyatakan dengan nilai 1 atau 0 , berturut-turut.

Lebih jauh, sebagai hasil kombinasi dari konsep $F S$ dan $S S$, diperkenalkan suatu teori yang disebut fuzzy soft set (FSS) oleh Maji et al. [5] pada tahun 2001. Pada teori FSS, setiap objek yang terkait dengan suatu parameter tertentu diberikan suatu nilai keanggotaan yang dinyatakan dengan suatu bilangan riil dalam interval $[0,1]$ dan parameter yang dipertimbangkan lebih dari satu sebagaimana halnya pada konsep $S S$.

Selanjutnya, Fatimah et al. [2] memperkenalkan suatu konsep baru yang disebut $N$-soft set (NSS) pada tahun 2018 yang merupakan perumuman dari SS. Teori NSS mengkaji tentang objek-objek yang diberi peringkat (grade) yang memenuhi suatu parameter tertentu, dimana grade tersebut merupakan suatu bilangan cacah yang kurang dari $N \in\{2,3,4, \ldots$.$\} . Lalu, pada$ tahun yang sama, Akram et al. [4] memperkenalkan suatu konsep yang disebut fuzzy $N$-soft set (FNSS) yang merupakan penggabungan dari konsep FS dan NSS. Dalam FNSS ini dikaji tentang grade dari setiap objek dan disertai dengan nilai keanggotaan dari objek tersebut untuk suatu parameter tertentu.

Pada tahun 2002, Maji and Roy [6] mengusulkan konsep reduct-SS. Konsep reduct-SS mengkaji tentang suatu himpunan bagian dari parameter-parameter pada suatu SS, yang dilibatkan dalam proses pengambilan keputusan, yang hasil keputusannya tidak berbeda dengan hasil keputusan yang melibatkan parameter-parameter lain yang disebut dengan dispensable set (himpunan parameter yang dapat diabaikan).

Termotivasi dari kajian tentang reduct-SS serta sudah diperkenalkannya konsep tentang FNSS maka menarik untuk dikaji bagaimana bentuk pola grade - grade dan nilai-nilai keanggotaan yang mungkin pada suatu FNSS sedemikian sehingga terdapat suatu dispensable set pada FNSS tersebut. Untuk melihat kemungkinan bentuk pola tersebut, maka pada artikel ini akan diberikan suatu kasus masalah pengambikan keputusan yang dapat disajikan dalam bentuk FNSS, sedemikian sehingga kasus tersebut memiliki dispensable set. Sehingga dari hasil penelaahaan ini, diharapkan ada penelitian selanjutnya yang dapat merumuskan kajian teoritisnya terkait dengan dispensable set pada suatu FNSS. 


\section{Fuzzy Set, N-Soft Set, Dan Fuzzy N-Soft Set}

Untuk memudahkan pemahaman terkait dengan topik dalam artikel ini, maka pada bagian ini akan ditinjau kembali definisi-definisi tentang FS, NSS, FNSS dan metode skor yang digunakan dalam proses penyelesaian masalah pengambilan keputusan.

Definisi 2.1. [3] Misalkan X adalah suatu himpunan dari objek-objek. Suatu fuzzy set A atas $X$ didefinisikan sebagai

$$
A=\left\{\left(x ; \mu_{A}(x)\right) \mid x \in X\right\}
$$

dimana $\mu_{A}: X \rightarrow[0,1]$ adalah fungsi keanggotaan, dan $\mu_{A}(x)$ adalah nilai keanggotaan dari $x \in X$ pada FS A.

Definisi 2.2. [2] Misalkan $U$ adalah himpunan dari objek-objek, E adalah himpunan dari parameter-parameter atau atribut-atribut dan $T \subseteq E$. Misalkan $G=\{0,1,2, \ldots, N-1\}$ adalah himpunan dari peringkat-peringkat dimana $N \in\{2,3,4, \ldots\}$. Suatu $N$-soft set atas $U$ yang dinotasikan dengan $(F, T, N)$ didefinisikan sebagai

$$
\begin{aligned}
(F, T, N) & =\left\{\left(t_{j}, F\left(t_{j}\right)\right) \mid t_{j} \in T\right\} \\
& =\left\{\left(t_{j},\left\{\left(u_{i}, g_{i j}\right) \mid u_{i} \in U\right\}\right) \mid t_{j} \in T\right\},
\end{aligned}
$$

dimana $F: T \rightarrow 2^{U \times G}$, dengan sifat bahwa untuk setiap $t_{j} \in T$, terdapat unik $\left(u_{i}, g_{i j}\right) \in U \times G$, sedemikian sehingga $\left(u_{i}, g_{i j}\right) \in F\left(t_{j}\right), u_{i} \in U, g_{i j} \in G$. Dalam hal ini, $g_{i j}$ adalah peringkat dari $u_{i}$ yang terkait dengan parameter $t_{j}$.

Definisi 2.3. [4] Misalkan $U$ adalah himpunan dari objek-objek, $E$ adalah himpunan dari parameter-parameter, $T \subseteq E$ dan $K=(F, T, N)$ adalah suatu NSS atas U. Suatu fuzzy $N$ soft set $(\mu, K)$ atas $U$ didefinisikan sebagai

$$
\begin{aligned}
(\mu, K) & =\left\{\left(t_{j}, \mu\left(t_{j}\right)\right) \mid t_{j} \in T\right\} \\
& =\left\{\left(t_{j},\left\{\left(\left(u_{i}, g_{i j}\right) ; f_{i j}\right) \mid u_{i} \in U\right\}\right) \mid t_{j} \in T\right\},
\end{aligned}
$$

dimana $\mu: T \rightarrow \bigcup_{t_{j} \in T} \mathcal{F}\left(F\left(t_{j}\right)\right)$ dengan $\mu\left(t_{j}\right)=\left\{\left(\left(u_{i}, g_{i j}\right) ; f_{i j}\right) \mid u_{i} \in U\right\}$ sedemikian sehingga $\mu\left(t_{j}\right) \in \mathcal{F}\left(F\left(t_{j}\right)\right), \forall t_{j} \in T$. Dalam hal ini, $\mathcal{F}\left(F\left(t_{j}\right)\right)$ adalah koleksi dari seluruh FS atas $F\left(t_{j}\right)$, $\left(u_{i}, g_{i j}\right) \in F\left(t_{j}\right)$ dan $f_{i j} \in[0,1]$ merupakan suatu nilai keanggotaan dari $\left(u_{i}, g_{i j}\right)$ yang terkait dengan parameter $t_{j}$.

Suatu FNSS dapat direpresentasikan dengan suatu tabel yang disebut Tabel Representasi dari FNSS yang disajikan pada Tabel 1.

TABEL 1. Tabel Representasi dari FNSS

\begin{tabular}{|c|c|c|l|c|}
\hline$(\mu, K)$ & $t_{1}$ & $t_{2}$ & $\cdots$ & $t_{q}$ \\
\hline$u_{1}$ & $\left(g_{11} ; f_{11}\right)$ & $\left(g_{12} ; f_{12}\right)$ & $\cdots$ & $\left(g_{1 q} ; f_{1 q}\right)$ \\
\hline$u_{2}$ & $\left(g_{21} ; f_{21}\right)$ & $\left(g_{22} ; f_{22}\right)$ & $\cdots$ & $\left(g_{2 q} ; f_{2 q}\right)$ \\
\hline$\vdots$ & $\vdots$ & $\vdots$ & $\cdots$ & $\vdots$ \\
\hline$u_{p}$ & $\left(g_{p 1} ; f_{p 1}\right)$ & $\left(g_{p 2} ; f_{p 2}\right)$ & $\cdots$ & $\left(g_{p q} ; f_{p q}\right)$ \\
\hline
\end{tabular}

Pada Tabel $1, u_{i} \in U, i=1, \ldots, p, t_{j} \in T, j=1, \ldots, q$, dengan $g_{i j}$ dalam setiap sel $(i, j)$ menunjukan bahwa $\left(u_{i}, g_{i j}\right) \in F\left(t_{j}\right)$ dan $f_{i j}$ merupakan suatu nilai keanggotaan dari $u_{i}$ dalam interval $[0,1]$ yang terkait dengan parameter $t_{j}$.

Kemudian, mengacu kepada konsep metode skor pada FSS [10], berikut didefinisikan suatu tabel lain dari FNSS yang akan digunakan dalam pembahasan. Dari suatu FNSS, dikonstruksi suatu tabel, dalam hal ini disimbolkan dengan Tabel $\mathrm{P}$ yang berukuran $p \times p$ dimana $p$ 
adalah banyaknya objek pada himpunan $U$. Setiap baris dan kolom ke- $i$ dari Tabel $\mathrm{P}$, disimbolkan dengan $u_{i}$ (objek ke- $i$ dari $U$ ). Suatu entri ke- $\{k, l\}$ di Tabel $\mathrm{P}$, yang disimbolkan dengan $c_{k l}$, menyatakan banyaknya parameter $t_{j}$ yang grade $g_{k j}$ lebih atau sama dengan grade $g_{l j}$ dan nilai keanggotaan $f_{k j}$ lebih atau sama dengan nilai keanggotaan $f_{l j}$, untuk $k, l=1,2, \ldots, p$.

Untuk setiap $k$, jumlah entri di baris ke- $k$ pada Tabel $\mathrm{P}$ yang bersesuaian dengan objek $u_{k}$ dilambangkan dengan $r_{k}$, yang dihitung dengan menggunakan rumus

$$
r_{k}=\sum_{l=1}^{p} c_{k l}
$$

Untuk setiap $l$, jumlah entri di kolom ke- $l$ pada Tabel $\mathrm{P}$ yang bersesuaian dengan objek $u_{l}$ dilambangkan dengan $t_{l}$, yang dihitung dengan menggunakan rumus

$$
t_{l}=\sum_{k=1}^{p} c_{k l} .
$$

Selanjutnya, untuk setiap $k$, didefinisikan skor dari objek $u_{k}$, yang dilambangkan dengan $S_{k}$, dan dihitung dengan menggunakan rumus

$$
S_{k}=r_{k}-t_{k}
$$

Seluruh nilai $r_{k}, t_{k}$ dan $S_{k}$ untuk setiap $u_{k}$ dinyatakan dalam suatu tabel yang dinamakan dengan tabel skor dari FNSS.

\section{Hasil Dan Pembahasan}

Pada bagian ini akan disajikan suatu kasus yang dapat direpresentasikan sebagai suatu FNSS yang memiliki dispensable set. Selanjutnya dilakukan perhitungan untuk mendapatkan hasil keputusan menggunakan tabel skor. Pada kasus ini penulis tidak secara rinci menjelaskan teknis dan ketepatan dalam proses mendapatkan data, karena hal tersebut tentunya memerlukan penelitian tersendiri dan mendalam yang melibatkan ahli yang sesuai dengan bidang yang dikaji. Jadi, kasus ini hanya lebih kepada suatu ilustrasi sebagai suatu bentuk aplikasi pada masalah pengambilan keputusan untuk menentukan dispensable set pada suatu FNSS. Kasus tersebut diselesaikan dengan membandingkan skor-skor dari objek-objek pada FNSS $(\mu, K)=(F, A, N)$ yang memuat dispensable set $T$ dengan skor-skor dari objek-objek pada FNSS $(\gamma, L)=(F, A-T, N)$ yang tanpa dispensable set $T$, sedemikian sehingga keputusan terhadap pemilihan objek-objek dari kedua FNSS tersebut adalah sama.

Kasus. Salah satu SMA Negeri di Kota Padang sedang menyeleksi siswa-siswa kelas X untuk dapat mengikuti program pertukaran pelajar. Ada beberapa tahapan seleksi untuk bisa lolos mengikuti program pertukaran pelajar ini. Misalkan $U=\left\{u_{1}, u_{2}, u_{3}, u_{4}\right\}$ adalah himpunan dari objek-objek berupa empat orang siswa kelas X yang akan diseleksi dan $A=\left\{a_{1}, a_{2}, a_{3}, a_{4}\right\}$ adalah himpunan dari atribut-atribut yang menyatakan jenis-jenis ujian dimana $a_{1}, a_{2}, a_{3}, a_{4}$ berturut-turut menyatakan pengetahuan tentang geografi dunia, pengetahuan tentang ekonomi dunia, pengetahuan tentang dunia olahraga dan tes psikotes. Pada tahapan pertama, setiap siswa diberikan sebuah soal pilihan berganda yang terdiri dari 25 pertanyaan untuk masing-masing jenis ujian. Setelah menyelesaikan tahapan pertama, setiap siswa diberi penilaian berupa peringkat $0,1,2, \ldots$, atau 6 berdasarkan berapa banyak jawaban yang benar dari masing-masing jenis ujian dengan ketentuan berikut ini.

1. peringkat " 0 " untuk tidak ada jawaban yang benar.

2. peringkat " 1 " untuk 1-5 jawaban yang benar.

3. peringkat " 2 " untuk 6-8 jawaban yang benar.

4. peringkat" 3 " untuk 9-12 jawaban yang benar.

5. peringkat" 4 " untuk 13-16 jawaban yang benar.

6. peringkat " 5 " untuk 17-20 jawaban yang benar.

7. peringkat " 6 " untuk 21-25 jawaban yang benar. 
Tahapan selanjutnya adalah tes esai. Pada tahapan ini, setiap siswa diberikan satu pertanyaan untuk masing-masing jenis ujian. Kemudian panitia seleksi akan memberikan penilaian terkait esai tersebut yang dinyatakan sebagai suatu bilangan riil dalam interval $[0,1]$ yang menyatakan tingkat "kesempurnaan" dari esai yang ditulis oleh siswa-siswa. Nilai-nilai ini merupakan nilai keanggotaan dari objek atau siswa yang terkait. Setelah proses penilaian dilakukan oleh seorang ahli yang merupakan seorang pengambil keputusan, misalkan diperoleh data, yang dapat dinyatakan dalam Tabel 2 sebagai suatu fuzzy 7 -soft set berikut ini.

TABEL 2. FrSS $(\mu, K)=(F, A, 7)$

\begin{tabular}{|c|c|c|c|c|}
\hline & $a_{1}$ & $a_{2}$ & $a_{3}$ & $a_{4}$ \\
\hline$u_{1}$ & $(4 ; 0,60)$ & $(3 ; 0,60)$ & $(3 ; 0,80)$ & $(2 ; 0,30)$ \\
$u_{2}$ & $(3 ; 0,40)$ & $(5 ; 0,70)$ & $(3 ; 0,70)$ & $(1 ; 0,20)$ \\
$u_{3}$ & $(2 ; 0,30)$ & $(6 ; 1,00)$ & $(2 ; 0,30)$ & $(3 ; 0,80)$ \\
$u_{4}$ & $(6 ; 0,90)$ & $(2 ; 0,20)$ & $(1 ; 0,10)$ & $(2 ; 0,50)$ \\
\hline
\end{tabular}

Jika diperhatikan data yang ada di kolom $a_{1}$ dan $a_{2}$ pada Tabel 2 , terdapat pola yang menarik sebagai berikut. Perhatikan pasangan peringkat dan nilai keanggotaan pada masingmasing sel atau entri yang ada di kolom $a_{1}$ dan $a_{2}$. Jika diurutkan peringkat dan nilai keanggotaan pada masing-masing kolom ini, dari yang terkecil sampai terbesar, dengan label 1,2,3 dan 4, maka akan didapatkan urutan pada kolom $a_{1}$, yang terkait dengan objek $u_{1}, u_{2}, u_{3}, u_{4}$ adalah $3,2,1,4$. Sedangkan pada kolom $a_{2}$ diperoleh urutannya 2,3,4,1. Jika dijumlahkan nomor urutan pada kolom $a_{1}$ dan urutan pada kolom $a_{2}$ untuk masing masing baris ke- $i$ (untuk setiap $u_{i}$ ) diperoleh masing-masingnya adalah 5 . Hal ini tentunya suatu hal yang menarik. Namun akan kita lihat selanjutnya, apa yang dapat disimpulkan terkait dengan skor dari setiap objek $u_{i}$, yang menjadi dasar dalam pengambilan keputusan, baik dengan melibatkan atribut $a_{1}$ dan $a_{2}$ atau tidak.

Selanjutnya diperoleh Tabel $\mathrm{P}$ dan tabel skor dari Tabel 2 seperti yang disajikan pada Tabel 3 dan Tabel 4 berturut-turut.

TABEL 3. Tabel $\mathrm{P}$ dari FNSS $(\mu, K)=(F, A, 7)$

\begin{tabular}{|c|c|c|c|c|}
\hline & $u_{1}$ & $u_{2}$ & $u_{3}$ & $u_{4}$ \\
\hline$u_{1}$ & 4 & 3 & 2 & 2 \\
$u_{2}$ & 1 & 4 & 2 & 2 \\
$u_{3}$ & 2 & 2 & 4 & 3 \\
$u_{4}$ & 2 & 2 & 1 & 4 \\
\hline
\end{tabular}

TABEL 4. Tabel skor dari $F N S S(\mu, K)=(F, A, 7)$

\begin{tabular}{|c|c|c|c|}
\hline & jumlah baris $\left(r_{i}\right)$ & jumlah kolom $\left(t_{i}\right)$ & skor akhir $\left(S_{i}\right)$ \\
\hline$u_{1}$ & 11 & 9 & 2 \\
$u_{2}$ & 9 & 11 & -2 \\
$u_{3}$ & 11 & 9 & 2 \\
$u_{4}$ & 9 & 11 & -2 \\
\hline
\end{tabular}

Dari Tabel 4 diperoleh bahwa $S_{1}=S_{3}>S_{2}=S_{4}$. Mengacu kepada FNSS pada Tabel 2, berikut diberikan $F N S S$ yang baru $(\gamma, L)=(F, A-T, 7)$, dimana $T=\left\{a_{1}, a_{2}\right\}$, seperti yang disajikan pada Tabel 5. Setelah itu ditentukan lagi Tabel $\mathrm{P}$ dan tabel skor dari $(\gamma, L)$, seperti yang disajikan pada Tabel 6 dan Tabel 7 berturut-turut.

Dari Tabel 7 diperoleh bahwa $S_{1}=S_{3}>S_{2}=S_{4}$. Dengan demikian, dari Tabel 4 dan Tabel 7 diperoleh bahwa skor-skor dari $u_{i}$ pada $\operatorname{FNSS}(\mu, K)=(F, A, 7)$ dan $F N S S$ 
TABEL 5. Tabel Representasi dari FNSS $(\gamma, L)=(F, A-T, 7)$

\begin{tabular}{|l|c|c|}
\hline & $a_{3}$ & $a_{4}$ \\
\hline$u_{1}$ & $(3 ; 0,80)$ & $(2 ; 0,30)$ \\
$u_{2}$ & $(3 ; 0,70)$ & $(1 ; 0,20)$ \\
$u_{3}$ & $(2 ; 0,30)$ & $(3 ; 0,80)$ \\
$u_{4}$ & $(1 ; 0,10)$ & $(2 ; 0,50)$ \\
\hline
\end{tabular}

TABel 6. Tabel P dari FNSS $(\gamma, L)=(F, A-T, 7)$

\begin{tabular}{|c|c|c|c|c|}
\hline & $u_{1}$ & $u_{2}$ & $u_{3}$ & $u_{4}$ \\
\hline$u_{1}$ & 2 & 2 & 1 & 1 \\
$u_{2}$ & 0 & 2 & 1 & 1 \\
$u_{3}$ & 1 & 1 & 2 & 2 \\
$u_{4}$ & 1 & 1 & 0 & 2 \\
\hline
\end{tabular}

TABEL 7. Tabel skor dari FNSS $(\gamma, L)=(F, A-T, 7)$

\begin{tabular}{|c|c|c|c|}
\hline & jumlah baris $\left(r_{i}\right)$ & jumlah kolom $\left(t_{i}\right)$ & skor akhir $\left(S_{i}\right)$ \\
\hline$u_{1}$ & 6 & 4 & 2 \\
$u_{2}$ & 4 & 6 & -2 \\
$u_{3}$ & 6 & 4 & 2 \\
$u_{4}$ & 4 & 6 & -2 \\
\hline
\end{tabular}

$(\gamma, L)=(F, A-T, 7)$ adalah sama, dengan artian bahwa hasil keputusan dari kedua FNSS tersebut adalah sama. Jadi $T$ merupakan suatu dispensable set.

Berdasarkan kasus ini, akan dapat diidentifikasi, kapan adanya suatu dispensable set dalam suatu FNSS. Salah satu pola, dimana suatu pasang atribut/parameter $(a, b)$ adalah suatu dispensable set, adalah bilamana jumlah label urutan dari pasangan peringkat dan nilai keanggotaan dari kedua atribut tersebut pada setiap objeknya, memiliki jumlah yang sama. Secara kongkrit dapat dijelaskan sebagai berikut. Misalkan $L_{i a}$ adalah label urutan dari suatu peringkat dan nilai keanggotaan dari objek ke- $i$ yang terkait dengan atribut $a$. Hal sama, didefinisikan juga $L_{i b}$ adalah label urutan dari suatu peringkat dan nilai keanggotaan dari objek ke- $i$ yang terkait dengan atribut $b$. Bilamana untuk setiap objek ke- $i, L_{i a}+L_{i b}=n$, untuk suatu $n$ bilangan asli, maka atribut $a$ dan $b$ tersebut adalah suatu dispensable set. Jadi, jika terdapat pasangan-pasangan parameter yang memenuhi kondisi seperti diatas, maka semua parameter tersebut merupakan dispensable set.

Hasil analisis dari kasus diatas, dapat diperoleh suatu gambaran bahwa pada suatu FNSS dimungkinkan adanya suatu dispensable set, sebagaimana kajian serupa pada NSS,FSS atau SS (lihat [7], [8], [9]). Tentunya akan terbuka peluang adanya variasi lain dari model urutan pasangan peringkat dan nilai keanggotaan pada suatu FNSS sedemikian sehingga akan ditemukan suatu dispensable set pada FNSS tersebut.

\section{Simpulan}

Dalam suatu proses pengambilan keputusan dalam rangka memilih objek yang terbaik, untuk suatu kasus yang dapat direpresentasikan sebagai suatu FNSS $(\mu, K)$, dapat digunakan suatu ukuran yang disebut dengan skor dari objek tersebut. Pada suatu FNSS, untuk sepasang parameter $(a, b)$ dari sekian parameter yang ada, dimungkinkan terdapatnya pola urutan dari peringkat dan nilai keanggotaan dari objek-objek, pada masing-masing parameter $a$ dan 
$b$ sedemikian sehingga, bilamana dihitung skor dari setiap objek tersebut, baik dengan mempertimbangkan parameter $a$ dan $b$ ataupun tidak, akan memberikan kesimpulan yang sama. Parameter-pamemeter sebagaimana halnya parameter $a$ dan $b$ ini, disebut dispensable set.

\section{DAFtar Pustaka}

[1] Molodtsov, D., 1999, Soft Set Theory, American Mathematical Society, 37, pp 19-31.

[2] Fatimah, F., Rosadi, D., Hakim, R. B. F. and Alcantud, J. C. R., 2018, N-Soft Set and Their Decision Making Algorithms, Soft Computing, 22, pp 3829-3842.

[3] Zadeh, L.A., 1965, Fuzzy Sets, Information and Control, 8, pp 338-356.

[4] Akram, M., Adeel, A. and Alcantud, J. C. R., 2018, Fuzzy N-Soft Sets : A Novel Model With Application, Journal of Intelligent and Fuzzy Systems, 35, pp 4757-4771.

[5] Maji, P. K., Biswas, R. and Roy, A. R., 2001, Fuzzy Soft Set Theory, Journal of Fuzzy Mathematics, 9, pp 589-602.

[6] Maji, P. K. and Roy, A. R., 2002, An Application of Soft Sets in A Decision Making Problem, Comput. Math. Appl., 44, pp 1077-1083.

[7] Akram, M., Ali, G., Alcantud, J. C. R. and Fatimah, F., 2020, Parameter Reductions in NSoft Sets and Their Applications in Decision-Making, Expert Systems, 2021;38:e12601. https : //doi.org/10.1111/exsy.12601.

[8] Chen, D., Tsang, E. C. C., Yeung, D. S. and Wang, X., 2005, The Parameterization Reduction of Soft Sets and Its Applications, Computers and Mathematics With Applications, 49, pp 757-763.

[9] Kong, Z., Ai, J., Wang, L., Li, P., Ma, L. and Lu, F., 2018, New Normal Parameter Reduction Method in Fuzzy Soft Set Theory, IEEE Access 7, pp 2986-2998.

[10] Roy, A. R. and Maji, P. K., 2007, A Fuzzy Soft Set Theoretic Approach to Decision Making Problems, Computational and Applied Mathematics, 203, pp 412-418. 